\title{
European proposal reopens debate over patenting of human genes
}

Munich. The European Commission is once again trying to clarify European patent law on biotechnological inventions by proposing a directive that would, among other things, explicitly allow patents on human genes isolated from the human body and on genetically altered animals and plants.

The proposed directive, which was published in Brussels last week, will be submitted for approval both to the Council of Ministers - the body representing the 15 member states of the European Union and to the European Parliament. A previous draft, which had already been approved by the council, was unexpectedly rejected by the parliament earlier this year, largely because of opposition to the idea of patents on human genes (see Nature 374, 103; 1995).

In the new draft, the commission has responded to certain of parliament's concerns. The text has been clarified (for example, on the distinction between 'discoveries' and 'inventions' and the concept of 'farmers' privilege' which gives farmers the right to breed or propagate from patented animals and plants for their own purposes), and by specifically excluding patents on germ-line therapy techniques.

Compassion in World Farming, a British pressure group opposed to genetic engineering of animals, has welcomed a clause in the draft directive that specifies that genetically modified animals may be patented only if the value to humans of the modification outweighs any suffering to the animal.

But in general, members of the Green group in the European Parliament, as well as other pressure groups concerned about the ethical aspects of genetic engineering, have already reacted critically to the new draft, saying that it remains "unacceptable" because it continues to allow patents on both genes and living organisms.

The new draft has been prepared under the direction of Mario Monti, the commissioner for the internal market and industrial affairs. He argues that the revised proposal "achieves the right balance between two equally essential requirements, [namely] promoting research and providing ethical protection".

Monti appears determined that, this time, the directive will be Monti: draft directive approved by the has 'the right balance'. parliament (the

embarrassment caused by the rejection of the first version was increased by the fact that it was the first time the parliament had used its recently increased powers to reject a directive approved by both the commission and European Union member states).

The new draft has therefore been drawn up after extensive consultation with both European parliamentarians and industrialists. It will also be discussed at a three-way public meeting between the parliament, commission and council on biotechnological issues, being held next month.

\section{AIDS patient given baboon bone marrow}

San Francisco. A pioneering experiment involving the first-ever transplantation of bone marrow into a human being is proceeding well, according to researchers from the University of California at San Francisco and the University of Pittsburgh.

Last week, Jeff Getty, a 38-year-old AIDS patient, received baboon bone marrow, in the hope that a mixture of baboon and human marrow could help to reconstitute his damaged immune system. Baboons are not susceptible to HIV, and, if the experiment is successful, the chimaeric bone marrow will begin producing immune system cells resistant to the virus.

Several days after the transplant, Getty was reported to be doing well. But doctors said he would remain vulnerable to neutropenia - a decrease in the number of neutrophilic leukocytes in the blood - and opportunistic infections for several weeks.
Researchers should be able to measure how well the baboon cells have taken in about four weeks, but doubt they will see any immune reconstitution in under six months.

The protocol for the experiment had been given strict scrutiny by federal authorities, partly because of concern that the might trigger the development of new viruses. Suzanne Ildstad, a researcher involved in the experiment, said that monitoring for such organisms has already begun, with samples being collected weekly for examination by collaborators throughout the world.

Formal guidelines for xenotransplantation are being developed by the Food and Drug Administration and the Centers for Disease Control. Ildstad praised Getty's bravery and said many patients might ultimately benefit. introduction of baboon cells into a human
Although some industry representatives doubt that the potential gains from a new directive will outweigh the public criticism the political debate is likely to generate, the commission has received backing from industrial lobby groups such as the Senior Advisory Group Biotechnology (SAGB) which represents around 30 biotechnology companies in Europe.

At the same time, environmentalist groups which successfully opposed the first draft of the directive argue that the commission's efforts to reopen the debate will provide them with a new opportunity for public expression of their concern.

One clause of the proposed directive likely to remain controversial seeks to clarify a passage in the European Patent Convention (EPC), which states that although animals and plants can be patented, animal and plant varieties cannot.

Those who oppose patents on living organisms argue that this should be interpreted to mean that, as new types of animals and plants can be considered as new collections of varieties, they are therefore unpatentable. Earlier this year, such an interpretation was accepted by an appeals board of the European Patent Office (EPO), which ruled that a patent granted to the Belgian company Plant Genetics Systems (PGS) on a procedure for producing pesticide-resistant plants could not cover the plants and seeds arising from the process (see Nature 374, 8; 1995).

An apparent corollary of this ruling that plants as such are not patentable - led Paul Braendli, EPO's president, to refer the decision to the EPO's highest legal authority, the Enlarged Board of Appeals, which judges on apparent conflicts between appeal board rulings. Braendli argued that the ruling was in conflict with earlier decisions to grant patents on plants.

Last week, however, the Enlarged Board of Appeals announced that Braendli's request for its adjudication was "inadmissible", as the PGS appeal board's decision was not, in its view, directly contradictory to previous rulings.

Left with a precedent for disallowing patenting of plants - which opponents to the patent on the Harvard oncomouse are already arguing should cover animals as well - the EPO now finds itself back to the beginning in its struggle to interpret its own rules, laid down in the EPC. The directive proposed by the commission gives no clearcut solution. But it does explicitly state that the exclusion of animal and plant varieties as such "does not prejudice the patentability of plants and animals". 